\title{
The peninsula effect on bird species in native eucalypt forests in a wood production landscape in Australia
}

\author{
D. P. Tubelis ${ }^{1}$, D. B. Lindenmayer ${ }^{1} \&$ A. Cowling ${ }^{2}$ \\ 1 Centre for Resource and Environmental Studies, The Australian National University, Canberra, ACT, Australia \\ 2 Statistical Consulting Unit, The Australian National University, Canberra, ACT, Australia
}

\section{Keywords}

birds; eucalypt forest; forest management; peninsula effect; spatial scale.

\section{Correspondence}

Dárius P. Tubelis. Current address: Departamento de Ecologia, Instituto de Biociências, Universidade de São Paulo, São Paulo, SP 05508-900, Brazil. Tel: +55 11 30712715; Fax: + 551438823732

Email: dtubelis@yahoo.com

Received 31 August 2005; accepted 11 April 2006

doi:10.1111/j.1469-7998.2006.00174.x

\begin{abstract}
The peninsula effect - a decrease in species richness from the base to the tip of a peninsula - has been tested for a diverse range of taxa at continental and regional scales. We investigated the peninsula effect at a local scale by examining bird species occurrence in riparian strips (peninsulas) of native eucalypt forest within a radiata pine plantation in the Tumut region, south-eastern Australia. Peninsulas were elongated but 'blind' extensions of a core area of native eucalypt forest. Birds were surveyed by the area search method, within 1.0-ha quadrats established along peninsulas $(n=14)$, in October and November 2002. Data were analysed using generalized linear mixed models. A significant decrease in bird species richness from the base towards the tip of the peninsulas was observed. The proportion of large bird species recorded per quadrat showed a significant decrease from the base towards the tip of the peninsulas. This pattern was not observed for small birds. Several species were more abundant at the base of the peninsulas than away from the core area of eucalypt forest. The peninsula effect can occur locally in landscape mosaics. Factors leading to the observed patterns of species occurrence may be distinct from those proposed in investigations of the peninsula effect with a biogeographical (macroscale) context. In our microscale study, foraging incursions of individual birds from the core area of native forest through peninsulas were a major factor giving rise to higher bird species richness in the more basal portions of peninsulas.
\end{abstract}

\section{Introduction}

In an investigation of the distribution of mammal species in North America, Simpson (1964) proposed the term 'peninsula effect' to describe the decline in species richness from the base to the tip of a peninsula. Since then, the peninsula effect has been tested for a diverse range of animals such as birds (Cook, 1969; Raivio, 1988; Wiggins, 1999), mammals (Taylor \& Regal, 1978; Seib, 1980; Lawlor, 1983), amphibians and reptiles (Kiester, 1971; Busack \& Hedges, 1984; Means \& Simberloff, 1987), and invertebrates (Due \& Polis, 1986; Brown, 1987). In these studies, peninsulas were extensions of the mainland of continents, such as Baja California and Florida. Few studies, however, have examined the peninsula effect in places other than continental projections. In one exception, Silva (1996) showed a decrease in the number of Amazonian and Atlantic forest bird species towards more central regions of the Brazilian savannas. In this case, riparian forests were peninsulas connected to originally forest-dominated ecosystems - the Amazon and the Atlantic Forest.

Patterns of species richness along peninsulas have not always been in agreement with predictions from the peninsula effect (see the review in Wiggins, 1999). As the peninsula effect has been questioned as a general phenomenon, more investigations of it are required in peninsulas worldwide (Means \& Simberloff, 1987).

Most investigations of the peninsula effect have been at continental or regional scales, with patterns of species distribution examined over tens or hundreds of kilometres (Wiggins, 1999). This study tested the peninsula effect on bird species at a local level in an inland patchy environment. This study was conducted in a 50000 ha exotic radiata pine Pinus radiata plantation at Tumut, south-eastern Australia. The plantation contains peninsulas of remnant native eucalypt forest connected to larger areas of native forest (termed 'core areas' in this study). Our first hypothesis was that bird species richness would decrease from the base towards the tip of the peninsulas of eucalypt forest. We supposed that this pattern would occur because, for several species, the core area of eucalypt forest would function as a source of birds that venture in the peninsulas to forage with fewer birds venturing to the distal end of peninsulas.

Our second hypothesis was that the strength of the peninsula effect would be different for large- and smallbodied birds. We supposed that decreases in species richness from the basal to distal portions of peninsulas would be more dramatic for large than for small bird species. This was 
because large birds usually have larger territory requirements than small ones (Schoener, 1968), thus making it likely that they would be more common in portions of peninsulas closer to the core area of eucalypt forest. To support the first two hypotheses, our third hypothesis was that the abundance of some bird species would decrease from the basal to more distal portions of peninsulas. We expected this to occur because birds inhabiting the core area of eucalypt forest would forage more often in nearby portions than in farther parts of peninsulas. We expected that the three hypotheses would be influenced by the width of peninsulas. Our results are discussed relative to other work on the peninsula effect and also in terms of bird conservation in managed landscapes.

\section{Study area}

The study was conducted in the Tumut region, southern New South Wales, in south-eastern Australia. An exotic plantation, primarily radiata pine, occupies a considerable part of the landscape, which was originally dominated by native eucalypt forest. The plantation, considered in this study as the 'matrix', surrounds remnants of the original eucalypt forest, such as riparian strips connected to an adjacent extensive core area of native forest. These strips of native forest, termed here 'peninsulas', are variable in length and width (Fig. 1). The length of selected peninsulas ranged from $800 \mathrm{~m}$ to $4 \mathrm{~km}$. Peninsulas were at least $400 \mathrm{~m}$ distant from each other.

\section{Methods}

\section{Study sites}

Fourteen sites (peninsulas of eucalypt forest) were selected for study. Peninsulas measuring between 50 and $70 \mathrm{~m}$ $(n=5)$, between 110 and $200 \mathrm{~m}(n=5)$ and between 300 and $700 \mathrm{~m}(n=4)$ in width were classified as 'narrow', 'intermediate' and 'very wide', respectively. The basal

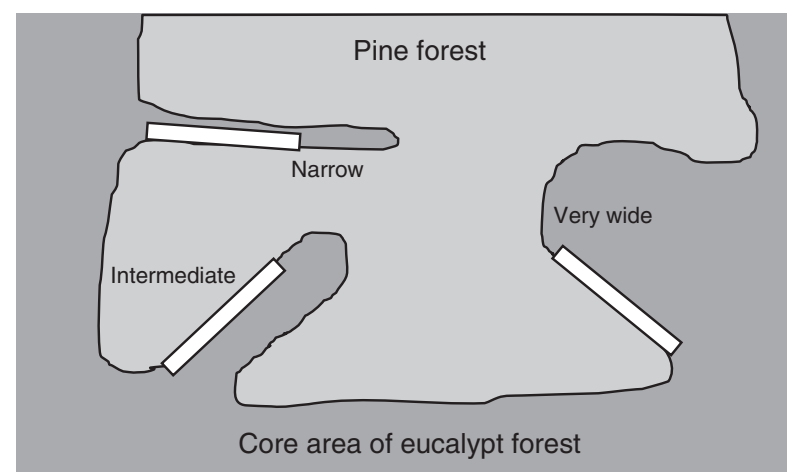

Figure 1 Schematic representation of narrow, intermediate and very wide peninsulas of eucalypt forest in a plantation of exotic pine forest at Tumut, New South Wales, Australia. The white areas indicate $(50 \mathrm{~m} \times 600 \mathrm{~m})$ surveyed areas of peninsulas, each including three adjacent quadrats. portions of peninsulas $(<0-200 \mathrm{~m}$ from the core area) were usually wider than the distal portions (Fig. 1). All peninsulas were 'blind' extensions of the core area, ending in a stand of pine forest, and not connected to other patches of eucalypt forest.

Two procedures were used to control for the influence of forest type on the results. First, only native forests dominated by narrow-leaved peppermint Eucalyptus radiata and ribbon gum Eucalyptus viminalis were selected. Second, only peninsulas with drainage lines close to the forest edge were selected to control for effects related to vegetation type and distance to forest edge (e.g. edge effects), respectively. To control for the influence of the matrix on bird occurrence in eucalypt peninsulas, all study sites were adjacent to pine forest aged between 22 and 28 years. These pine forests have similar structure as they have been subject to one thinning operation. Also, the pine trees are of similar size and the native understory is comparable.

\section{Bird surveys}

Three quadrats (each measuring $50 \mathrm{~m} \times 200 \mathrm{~m}$ ) were established at each study site. These 1.0-ha quadrats were located with their longest axes facing parallel to the boundary line (an unsealed road about $7 \mathrm{~m}$ in width) separating the eucalypt and pine forests. Quadrats were located adjacent to each other along the edge of peninsulas $(0-50 \mathrm{~m}$ from the boundary line). At each site, the quadrats were located at three positions $(0-200,200-400$ and $400-600 \mathrm{~m})$ in relation to the core area of eucalypt forest.

Surveys were conducted between early October and late December 2001, which corresponds to the breeding period of most forest bird species in this region (Lindenmayer et al., 2002). To avoid confounding seasonal variation and treatment, the three types of peninsulas were surveyed alternatively within a period of 3 weeks. After completing one survey of all study sites, all sites were surveyed again within a comparable period.

Birds were surveyed by the area search method within quadrats (Cunningham et al., 1999; Bibby et al., 2000) by one observer (D. P. T.). In each sample, each quadrat was searched for $10 \mathrm{~min}$, recording all birds heard or seen within the limits of the quadrat. Birds flying over the forest and birds crossing a quadrat without landing were not recorded. Two study sites were sampled in the same morning, between sunrise and 09:30 h. Time-of-morning biases were controlled by (1) sampling the three peninsula types alternatively in the earlier and later period of mornings and (2) randomly selecting the order of sampling of the three positions before starting the survey in a given peninsula. Sampling within such narrow quadrats minimized problems related to distinct detectabilities of different species, as most birds recorded during a sample were heard and seen.

\section{Analyses}

We analysed the effect of the position of quadrats within peninsulas ('position') and of the width of peninsulas 
('width') on bird occurrence in peninsulas. As we conducted surveys in two periods, analyses were based on 84 samples from 42 quadrats, from 14 peninsulas ('sites'). Four response variables were examined:

- the number of species (species richness) detected at each quadrat in each peninsula;

- the proportion of large bird species detected at each quadrat in each peninsula;

- the proportion of small bird species detected at each quadrat in each peninsula;

- the number of individual birds (abundance) of a given species detected at each quadrat in each peninsula. The pied currawong Strepera graculina was selected for this analysis because of its occurrence along several peninsulas.

We used generalized linear mixed models (Schall, 1991) for all analyses, with 'position', 'width' and their interaction as fixed effects, and 'period' and 'site' as random effects. We used Poisson models when the response was the number of species and the number of birds, and binomial models when the response was a proportion. Wald tests were used to assess the significance of the fixed effects. In most cases, the model was overdispersed. Overdispersion was estimated and used to adjust the test statistics.

Bird species weighing more than $90 \mathrm{~g}$ were classified as 'large' bird species, whereas those weighing less than $90 \mathrm{~g}$ were classified as 'small' bird species, following Lindenmayer et al. (2002). The proportion of large bird species at each position was calculated by dividing the number of large bird species recorded in that position by the total number of large bird species recorded in our study $(n=13)$. The same procedure was completed for the small birds, of which 24 species were recorded.

\section{Results}

\section{Bird species richness along the peninsulas}

There were significant effects of position $(P=0.006)$ and width $(P<0.001)$ on bird species richness found along peninsulas. The interaction between these two variables was not significant $(P=0.283)$. Bird species richness decreased towards more distal parts of peninsulas, for all classes of peninsula width considered. The rate of decrease was the same for narrow, intermediate and very wide peninsulas (Fig. 2).

\section{Occurrence of large and small birds along the peninsulas}

Patterns of occurrence of large and small bird species varied along the peninsulas, and also varied with the width of peninsulas (Fig. 3). In narrow peninsulas, the proportion of small bird species did not show significant differences between the three positions. However, the proportion of large birds was significantly lower in the 400-600 $\mathrm{m}$ band than in more basal portions of peninsulas (Fig. 3). The proportions of both large and small bird species showed no significant differences along peninsulas of intermediate

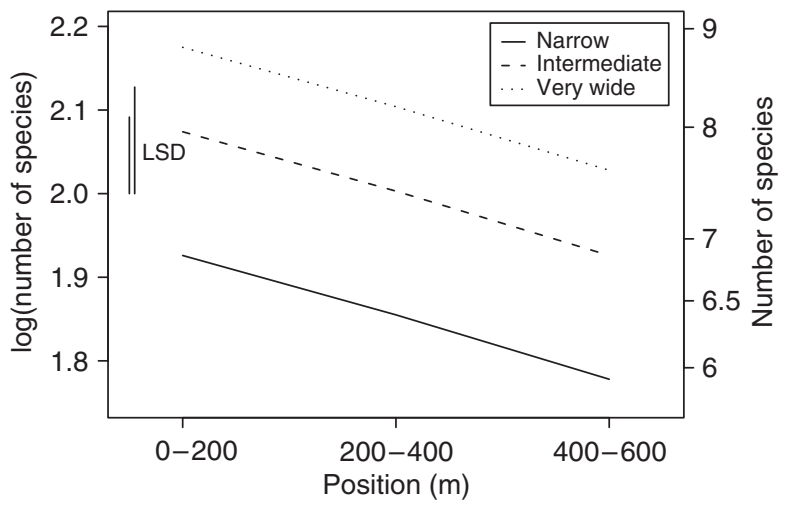

Figure 2 Bird species richness recorded along narrow, intermediate and very wide peninsulas of eucalypt forest in a radiata pine Pinus radiata plantation at Tumut, New South Wales, Australia. Position refers to distance from a core area of eucalypt forest adjacent to the plantation. The least significant difference (LSD) on the left is for comparison between position at the same level of width, whereas the LSD on the right is for comparison between width at the same level of position.

width. In very wide peninsulas, the proportion of small bird species was similar along the peninsulas. However, the proportion of large bird species was significantly higher at the $0-200 \mathrm{~m}$ band than in portions more distant from the core area of eucalypt forest.

\section{Patterns of individual species occurrence along the peninsulas}

There were significant differences $(P=0.001)$ in the abundance of the pied currawong at the three positions along peninsulas (Fig. 4; Table 1). It was significantly more numerous in the $0-200$ and $200-400 \mathrm{~m}$ bands than in the $400-600 \mathrm{~m}$ distance band from the core eucalypt forest. There were also differences between peninsula width $(P=0.041)$, with more individuals being recorded in intermediate and very wide peninsulas than in narrow peninsulas (Fig. 4).

Several species tended to occur in higher numbers in the base of peninsulas, although differences were not significant (Table 1). These taxa included both small species such as the white-naped honeyeater Melithreptus lunatus and the eastern spinebill Acanthorhynchus tenuirostris, and large birds such as the red wattlebird Annthochaera carunculata, the noisy friarbird Philemon corniculatus, and the sulphurcrested cockatoo Cacatua galerita (Table 1).

\section{Discussion}

\section{Overview}

The results of some investigations support the peninsula effect whereas others do not (Wiggins, 1999). It was found that diverse patterns of species richness other than the 

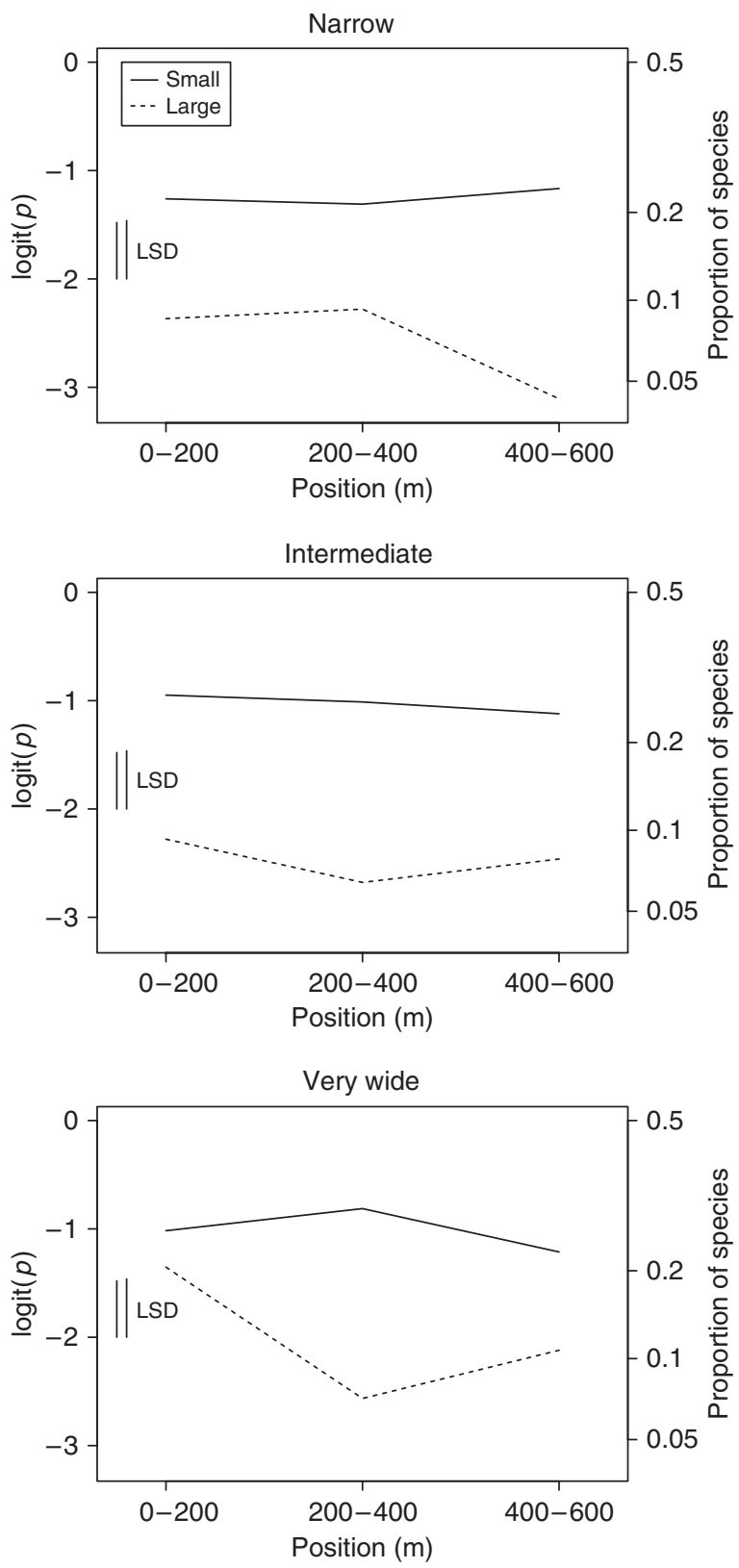

Figure 3 Proportions of small and large bird species along narrow, intermediate and very wide peninsulas of eucalypt forest in a radiata pine Pinus radiata plantation at Tumut, New South Wales, Australia. Position refers to distance from a core area of eucalypt forest adjacent to the plantation. The least significant difference (LSD) on the left is for comparison between position at the same level of size, whereas the LSD on the right is for comparison between size at the same level of position.

decline from the base towards the tip of a peninsula have been found in several studies. For example, species richness can be uniform along a peninsula or show substantial changes along its extension. In some studies, highest species richness was found in the distal parts of peninsulas and in

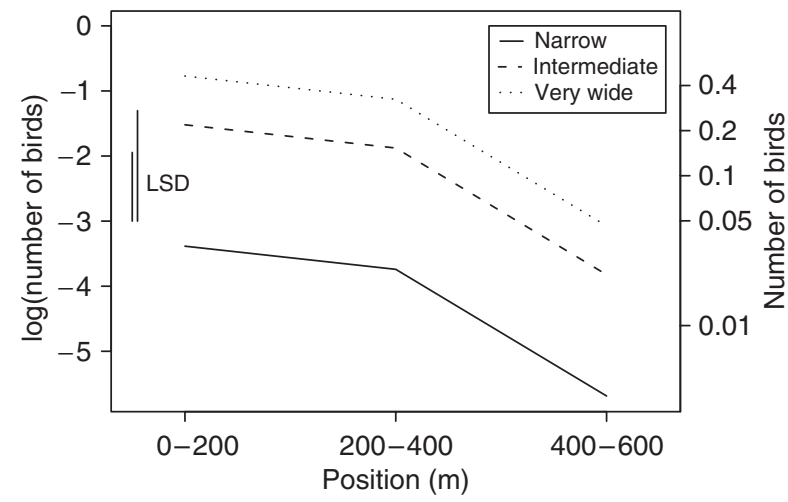

Figure 4 Abundance of the pied currawong Strepera graculina along narrow, intermediate and very wide peninsulas of eucalypt forest in a radiata pine Pinus radiata plantation at Tumut, New South Wales, Australia. Position refers to distance from a core area of eucalypt forest adjacent to the plantation. The least significant difference (LSD) on the left is for comparison between position at the same level of width, whereas the LSD on the right is for comparison between width at the same level of position.

other studies in the middle parts of peninsulas (Wiggins, 1999).

In this study, the observed decreasing values of species richness along peninsulas with increasing distances from the core area of eucalypt forest were in agreement with predictions of the peninsula effect and hence with our first hypothesis. This effect has been demonstrated for a diverse range of groups in oceanic peninsulas (Simpson, 1964; Cook, 1969; Kiester, 1971; Taylor \& Regal, 1978; Busack \& Hedges, 1984; Means \& Simberloff, 1987) and inland peninsulas (Silva, 1996). As these other investigations considered continental or regional scales, our study is the first we are aware of to document the peninsula effect at a local scale.

\section{Factors leading to patterns of species richness along peninsulas}

A diverse range of factors has been proposed to explain patterns of species richness along peninsulas (Wiggins, 1999). Simpson (1964) considered that decreasing species richness from basal to more distal parts of peninsulas would occur due to immigration-extinction dynamics. This explanation has been supported in several studies of the peninsula effect but rejected in others (Wiggins, 1999). We consider that such dynamics might not influence bird species richness along the peninsulas of eucalypt forest because of the small spatial scale adopted in our study. However, research on dispersal and population biology would be necessary to further examine our conclusion.

Factors related to habitat change along peninsulas, such as variation in habitat suitability, floral diversity and habitat heterogeneity, have been posed as alternative explanatory factors influencing species occurrence in peninsulas (Seib, 1980; Lawlor, 1983; Brown, 1987; Means \& Simberloff, 
Table 1 Abundance (number of individuals) of bird species in peninsulas of eucalypt forest surrounded by exotic pine forest, at three positions from the core area of eucalypt forest, in southern New South Wales, Australia

\begin{tabular}{|c|c|c|c|c|}
\hline \multirow[b]{2}{*}{ Bird species } & \multirow[b]{2}{*}{ Weight (g) } & \multicolumn{3}{|c|}{ Position (m) } \\
\hline & & $0-200$ & $200-400$ & $400-600$ \\
\hline Brown thornbill Acanthiza pusilla & 7 & 62 & 72 & 64 \\
\hline Striated thornbill Acanthiza lineata & 7 & 0 & 4 & 4 \\
\hline Rose robin Petroica rosea & 8 & 1 & 2 & 1 \\
\hline Spotted pardalote Pardalotus punctatus & 8 & 6 & 6 & 7 \\
\hline Grey fantail Rhipidura fuliginosa & 8 & 74 & 72 & 70 \\
\hline Rufous fantail Rhipidura rufifrons & 10 & 2 & 0 & 0 \\
\hline Silvereye Zosterops lateralis & 10 & 9 & 8 & 2 \\
\hline Eastern spinebill Acanthorhynchus tenuirostris & 10 & 4 & 0 & 0 \\
\hline Striated pardalote Pardalotus striatus & 11 & 4 & 2 & 4 \\
\hline White-browed scrub-wren Sericornis frontalis & 12 & 76 & 76 & 74 \\
\hline Scarlet robin Petroica multicolor & 13 & 0 & 3 & 4 \\
\hline Leaden flycatcher Myiagra rubecula & 13 & 3 & 2 & 1 \\
\hline White-naped honeyeater Melithreptus lunatus & 13 & 8 & 6 & 0 \\
\hline Yellow-faced honeyeater Lichenostomus chrysops & 16 & 92 & 97 & 96 \\
\hline Eastern yellow robin Eopsaltria australis & 19 & 2 & 1 & 7 \\
\hline White-eared honeyeater Lichenostomus leucotis & 20 & 0 & 1 & 0 \\
\hline White-throated treecreeper Cormobates leucophaea & 22 & 20 & 16 & 15 \\
\hline Red-browed treecreeper Climacteris erythrops & 24 & 0 & 1 & 0 \\
\hline Golden whistler Pachycephala pectoralis & 25 & 15 & 13 & 10 \\
\hline Rufous whistler Pachycephala rufiventris & 25 & 14 & 10 & 13 \\
\hline Crested shrike-tit Falcunculus frontatus & 28 & 1 & 0 & 0 \\
\hline Fan-tailed cuckoo Cuculus flabelliformis & 54 & 2 & 2 & 0 \\
\hline Eastern whipbird Psophodes olivaceus & 57 & 6 & 7 & 4 \\
\hline Grey shrike-thrush Colluricincla harmonica & 63 & 2 & 11 & 11 \\
\hline Olive-backed oriole Oriolus sagittatus & 96 & 0 & 0 & 2 \\
\hline Grey butcherbird Cracticus torquatus & 97 & 0 & 1 & 0 \\
\hline Bassian thrush Zoothera lunulata & 108 & 2 & 0 & 3 \\
\hline Red wattlebird Anthochaera carunculata & 110 & 13 & 3 & 6 \\
\hline Noisy friarbird Philemon corniculatus & 117 & 2 & 2 & 0 \\
\hline Crimson rosella Platycercus elegans & 128 & 28 & 31 & 24 \\
\hline Black-faced cuckoo-shrike Coracina novaehollandiae & 134 & 0 & 0 & 0 \\
\hline Australian king parrot Alisterus scapularis & 205 & 2 & 2 & 2 \\
\hline Gang-gang cockatoo Callocephalon fimbriatum & 219 & 2 & 0 & 3 \\
\hline Pied currawong Strepera graculina & 287 & 10 & 7 & 1 \\
\hline Laughing kookaburra Dacelo novaeguineae & 336 & 6 & 2 & 5 \\
\hline White-winged chough Corcorax melanorhamphos & 359 & 4 & 4 & 0 \\
\hline Sulphur-crested cockatoo Cacatua galerita & 500 & 16 & 10 & 12 \\
\hline Superb lyrebird Menura novaehollandiae & 975 & 2 & 0 & 0 \\
\hline
\end{tabular}

Species are ordered by increasing body weight.

1987; Wiggins, 1999). We consider that these are not major factors influencing bird occurrence in the eucalypt peninsulas we investigated. This is because quadrats were established along forest edges and close to drainage lines. Moreover, there was little variation in the floristic composition and in the structure of vegetation along the peninsulas.

Historical factors such as geological events, palaeogeographic legacy and in situ speciation (Busack \& Hedges, 1984; Due \& Polis, 1986; Brown, 1987) have also been considered as probable explanations for patterns of species distribution in peninsulas. We consider that these factors are unlikely to influence variation in bird occurrence along the eucalypt peninsulas because of the temporal scale of our study - the peninsulas were created only $20-30$ years ago by plantation establishment in the surrounding matrix. It is also unlikely that topographic barriers (Lawlor, 1983) and climatic patterns (Brown, 1987) influenced species occurrence along eucalypt peninsulas because of the spatial scale we examined - variation over just hundreds of metres.

Proximity to the mainland might also influence species occurrence in oceanic peninsulas by immigration through the sea (Brown, 1987; Wiggins, 1999). We consider that bird occurrence in the eucalypt peninsulas might be affected by movements, through the pine forest, from the core area of eucalypt forest, or from other peninsulas and forest remnants embedded in the pine plantation. We, however, did 
not note movements from other forest remnants (peninsulas or fragments) during the surveys. Also, we considered that birds (especially species typical of woodlands) inhabiting the pine matrix might influence occurrence in the peninsulas. However, as peninsulas were within homogeneous stands of pine forest, the surrounding pine matrix probably did not cause substantial variation in bird occurrence along the peninsulas.

Two major factors might have contributed substantially to the peninsula effect identified in our study. First, the core area of eucalypt forest functioned as a source of birds that made foraging incursions in the peninsulas. Outside the specific sample times of this study, we made many incidental observations of individuals of species such as the pied currawong, the red wattlebird An. carunculata, the noisy friarbird $P$. corniculatus, the eastern spinebill Ac. tenuirostris, the sulphur-crested cockatoo $C$. galerita, the whitenaped honeyeater $M$. lunatus and the olive-backed oriole Oriolus sagittatus moving along peninsulas from the core area, spending variable amounts of time in the peninsulas and then moving back to the core area. As a result of this movement, the abundance of particular species and bird species richness might decline with increasing distance from the core area of native forest, in a way similar to patterns found across patch-matrix boundaries (e.g. Tubelis, Cowling \& Donnelly, 2004). More limited use of more distal portions of peninsulas by individuals, depending on the core area, might result from factors related to the central place theory (Pyke, Pulliam \& Charnov, 1977; Recher et al., 1987). For such birds, relatively high foraging efficiency and low nest predation threat might be experienced when expanding territories only to more basal (and not to distal) parts of peninsulas.

A second factor leading to higher numbers of species in the more basal portions of peninsulas might be the variation in width of eucalypt forests. In all peninsulas, the $0-200 \mathrm{~m}$ position was slightly wider than the other two positions. Thus, higher numbers of species and of birds in the base $(0-200 \mathrm{~m})$ of peninsulas might reflect habitat width, as several bird species are sensitive to the size of forest remnants in the study area (Lindenmayer et al., 2002). This might explain part of the variation between the more basal $(0-200 \mathrm{~m})$ and the other two sampled parts of peninsulas. However, width had no effect on variation between the 200-400 and 400-600 m positions because each surveyed peninsula had a uniform width along most of its extension.

\section{Peninsula effect among distinct groups of species}

Comparisons between classes of vertebrates are frequent in investigations of the peninsula effect (Kiester, 1971; Seib, 1980; Busack \& Hedges, 1984; Means \& Simberloff, 1987; Wiggins, 1999). Studies also examined have differences between categories of species within a vertebrate class or within an order of arthropods. It has been shown that the geographical origin of species of reptiles (Seib, 1980), bats
(Lawlor, 1983), butterflies (Brown, 1987) and birds (Silva, 1996), and the elevational distribution of bird species (Wiggins, 1999) can influence patterns of species richness along a peninsula.

Our study showed that large- and small-bodied bird species responded differently to the proximity to the core area of eucalypt forest. This is in agreement with our second hypothesis - that decreases in species richness from the more basal to more distal portions of peninsulas would be more dramatic for large than for small bird species. This might have occurred because territory sizes tend to be proportional to the body mass of species (Schoener, 1968). Accordingly, the proportion of large bird species declined with increasing distances from the core area probably because a considerable percentage of these large species might have large area requirements. Thus, most individuals of these species might depend on the core area and/or on the wide base of peninsulas to survive. The proportion of small bird species did not vary substantially along peninsulas probably because a considerable number of these species might be able to inhabit peninsulas independent of larger areas of native forest, like the core area and the wider bases of peninsulas.

There were exceptions for the body weight response. Some small bird species, such as the eastern spinebill and the white-naped honeyeater, tended to be more numerous at the base than at distal portions of all peninsulas. They were frequently observed moving from the core area to more basal portions of peninsulas.

\section{Influence of peninsula width}

Most studies on the peninsula effect have sampled a single peninsula (Kiester, 1971; Taylor \& Regal, 1978; Seib, 1980; Lawlor, 1983; Due \& Polis, 1986; Brown, 1987; Means \& Simberloff, 1987; Wiggins, 1999). The few studies that examined species richness along several peninsulas (Simpson, 1964; Cook, 1969; Busack \& Hedges, 1984) have shown that the peninsula effect was not present in all of them, thus suggesting that the peninsula effect was not a concomitant feature of peninsulas. Our approach in a landscape mosaic permitted the sampling of several replicate peninsulas with different widths.

The rates of decrease of species richness and the abundance of the pied currawong were similar for the three categories of peninsula width. However, peninsula width influenced the occurrence of large bird species along their extensions. More pronounced declines in the proportion of large species occurred in more distal portions of narrow peninsulas and in more basal portions of very wide peninsulas. Most species coming from the core area might have ventured up to $400 \mathrm{~m}$ in the narrow peninsulas and up to $200 \mathrm{~m}$ in very wide peninsulas. It is likely that forest area (e.g. Lindenmayer et al., 2002) and edge effects (Laurance et al., 2002) are major factors contributing to the patterns observed. For example, some bird species might not venture into narrow peninsulas because of their low quantity of native forest and high proportions of edge habitat. 


\section{Conservation issues}

The decrease in species richness in peninsulas with increasing distances from adjacent protected reserves (the core area) of eucalypt forest has implications for assessments of the conservation value of linear forest strips for birds. Such investigations are frequent worldwide (e.g. Recher et al., 1987; Lindenmayer, Cunningham \& Donnelly, 1993; Darveau et al., 1995; Bentley \& Catterall, 1997; Hagar, 1999; Sieving, Willson \& de Santo, 2000; Hannon et al., 2002) and are essential in many managed landscapes. Similar future studies conducted near extensive forest reserves could consider distance to these protected areas as an explanatory variable. Proximity to extensive native areas that are a source of species might lead to overestimates of the value of linear strips for bird species. This is because foraging incursions from reserves can influence estimates of species richness in peninsulas (this study), similar to what has been discussed for assessments of managed or exotic vegetation for birds (Tubelis, 2005).

Further, at Tumut, forest managers could prioritize the conservation of eucalypt remnants located close to core areas of native forest, as they harbour higher species richness and greater bird abundance than areas of native forest distant from these preserved continuous forests. However, native forest areas distant from the core areas of native forest (more distal portions of peninsulas) should also be conserved as they are used by a considerable number of bird species.

\section{Concluding remarks}

Our study showed that the peninsula effect might occur in two situations very distinct from those tested previously. First, this principle might occur inland, in landscape mosaics. Second, the peninsula effect may occur at a scale smaller than has been previously examined. We consider that a major factor contributing to decreasing values of species richness from the base towards the tip of peninsulas are foraging incursions of species moving from core areas. This is analogous to the immigration factor proposed to explain the peninsula effect in oceanic peninsulas (Simpson, 1964).

\section{Acknowledgements}

We thank State Forests of New South Wales for providing field facilities. The fieldwork was financed by grants from CSIRO and David B. Lindenmayer. D. P. T.'s PhD study at CRES was supported by a scholarship (No. 200102-00/1) from the Brazilian Council of Science and Technology (CNPq). C. P. Catterall, S. J. Hannon, S. G. W. Laurance and D. Saunders greatly improved this manuscript with very constructive suggestions. D. P. T. was granted a fellowship (No. 05/03466-4) from FAPESP during the completion of the writing process of this paper.

\section{References}

Bentley, J.M. \& Catterall, C.P. (1997). The use of bushland, corridors, and linear remnants by birds in southeastern Queensland, Australia. Conserv. Biol. 11, 1173-1189.

Bibby, C.J., Burgess, N.D., Hill, D.A. \& Mustoe, S.H. (2000). Bird census techniques. London: Academic Press.

Brown, J.W. (1987). The peninsular effect in Baja California: an entomological assessment. J. Biogeogr. 14, 359-365.

Busack, S.D. \& Hedges, S.B. (1984). Is the peninsular effect a red herring? Am. Nat. 123, 266-275.

Cook, R.E. (1969). Variation in species density of North American birds. Syst. Zool. 18, 63-84.

Cunningham, R.B., Lindenmayer, D.B., Nix, H.A. \& Lindenmayer, B.C. (1999). Quantifying observer heterogeneity in bird counts. Aust. J. Ecol. 24, 270-277.

Darveau, M., Beauchesne, P., Bélanger, L., Huot, J. \& Larue, P. (1995). Riparian forest strips as habitat for breeding birds in boreal forest. J. Wildl. Mgmt. 59, 67-78.

Due, A.D. \& Polis, G.A. (1986). Trends in scorpion diversity along the Baja California Peninsula. Am. Nat. 128, 460-468.

Hagar, J.C. (1999). Influence of riparian buffer width on bird assemblages in western Oregon. J. Wildl. Mgmt. 63, 484-496.

Hannon, S.J., Paszkowski, C.A., Boutin, S., DeGroot, J., Macdonald, S.E., Wheatley, M. \& Eaton, B.R. (2002). Abundance and species composition of amphibians, small mammals, and songbirds in riparian forest buffer strips of varying widths in the boreal mixedwood of Alberta. Can. J. For. Res. 32, 1784-1800.

Kiester, A.R. (1971). Species density of North American amphibians and reptiles. Syst. Zool. 20, 127-137.

Laurance, W.F., Lovejoy, T.E., Vasconcelos, H.L., Bruna, E.M., Didham, R.K., Stouffer, P.C., Gascon, C., Bierregaard, R.O. Jr., Laurance, S.G. \& Sampaio, E. (2002). Ecosystem decay of Amazonian forest fragments: a 22-year investigation. Conserv. Biol. 16, 605-618.

Lawlor, T.E. (1983). The peninsula effect on mammalian species diversity in Baja California. Am. Nat. 121, 432-439.

Lindenmayer, D.B., Cunningham, R.B. \& Donnelly, C.F. (1993). The conservation of arboreal marsupials in the montane ash forests of the Central Highlands of Victoria, south-east Australia. IV. The distribution and abundance of arboreal marsupials in retained linear strips (wildlife corridors) in timber production forests. Biol. Conserv. 66, 207-221.

Lindenmayer, D.B., Cunningham, R.B., Donnelly, C.F., Nix, H.A. \& Lindenmayer, B.D. (2002). Effects of forest fragmentation on bird assemblages in a novel landscape context. Ecol. Monogr. 72, 1-18.

Means, D.B. \& Simberloff, D. (1987). The peninsula effect: habitat-correlated species decline in Florida's herpetofauna. J. Biogeogr. 14, 551-568.

Pyke, G.H., Pulliam, H.R. \& Charnov, E.L. (1977). Optimal foraging in a selective review of theory and tests. $Q$. Rev. Biol. 52, 137-154. 
Raivio, S. (1988). The peninsular effect and habitat structure - bird communities in coniferous forests of the Hanko peninsula, southern Finland. Ornis Fennica 65, 129-149.

Recher, H.F., Shields, J., Kavanagh, R.P. \& Webb, G. (1987). Retaining remnant mature forest for nature conservation at Eden, New South Wales: a review of theory and practice. In Nature conservation: the role of remnants of vegetation: 177-194. Saunders, D.A., Arnold, G.W., Burbidge, A.A. \& Hopkins, A.J. (Eds). Chipping Norton: Surrey Beatty and Sons.

Schall, R. (1991). Estimation in generalized linear mixed models with random effects. Biometrika 78, 719-727.

Schoener, T.W. (1968). Sizes of feeding territories among birds. Ecology 49, 123-141.

Seib, R.L. (1980). Baja California: a peninsula for rodents but not for reptiles. Am. Nat. 115, 613-620.

Sieving, K.E., Willson, M.F. \& de Santo, T.L. (2000). Defining corridor functions for endemic birds in fragmented south-temperate rainforest. Conserv. Biol. 14, 1120-1132.
Silva, J.M.C. (1996). Distribution of Amazonian and Atlantic birds in gallery forests of the Cerrado region, South America. Ornitol. Neotrop. 7, 1-18.

Simpson, G.G. (1964). Species density of North American recent mammals. Syst. Zool. 13, 57-73.

Taylor, R.J. \& Regal, P.J. (1978). The peninsula effect on species diversity and the biogeography of Baja California. Am. Nat. 112, 583-593.

Tubelis, D.P. (2005). Patch-matrix interactions and bird species conservation in a managed forest landscape in Australia. PhD thesis, The Australian National University at Canberra.

Tubelis, D.P., Cowling, A. \& Donnelly, C. (2004). Landscape supplementation in adjacent savannas and its implications for the design of corridors for forest birds in the central Cerrado, Brazil. Biol. Conserv. 118, 353-364.

Wiggins, D.A. (1999). The peninsula effect on species diversity: a reassessment of the avifauna of Baja California. Ecography 22, 542-547. 